Atomic Energy Authority ; Sir Lindor Brown, biological secretary of the Royal Society, Jodrell professor of physiology at University College, London; Sir William Hodge, physical secretary of the Royal Society, Lowndean professor of astronomy and geometry in the University of Cambridge; Dr. H. G. Thornton, foreign secretary of the Royal Society, lately head of the Department of Soil Microbiology at Rothamsted Experimental Station; Sir Patrick Linstead, rector of the Imperial College of Science and Technology; and Prof. Wilson Smith, professor of bacteriology at University College Hospital Medical School in the University of London.

\section{Biology at Middlesex Hospital Medical School: Prof. J. H. Woodger}

Prof. J. H. Woodger has just retired from the Middlesex Hospital Medical School after thirty-seven years as head of the Department of Biology. He graduated at University College, London, in 1914 and returned as assistant in zoology after four years active service, mainly in Mesopotamia, before accepting an appointment in the Middlesex Hospital Medical School at the age of twenty-eight. At a very early stage in his career, Woodger discerned that much of what passed for 'zoological philosophy' was a hotch-potch of confused thinking based upon an inattentive or insufficiently analytical use of words. In his "Biological Principles" of 1929 he did his utmost to dissect some of the stock antitheses of biology-for example, the antithesis between preformation and epigenesis - with the resources of ordinary language; but ordinary language proved too elumsy and imprecise, and Woodger's thoughts accordingly turned to the logical symbolism of Russell and Whitehead's "Principia Mathematica", enriched by the addition of many empirical constants for ideas which (unlike number or similarity) cannot be defined by logical concepts alone. His "Axiomatic Method in Biology" of 1937 was the first attempt to 'axiomatize' biology, that is, to cast it in the form of theorems logically deducible from a small number of axioms or postulates. Woodger has an international reputation as a logician; his "Technique of Theory Construction" of 1939 is a splendid exposition of the modern ideas on scientific methodology that arose mainly from the work of Karl Popper. Woodger's fine analytical work was continued in his Tarner Lectures of 1949-50 and is still actively in progress. His attempts at axiomatization have been thought premature by some who are competent to express an opinion; but the attempt to import rigour and precision into biological thinking was very much overdue, and Woodger's writing and thinking have had a quiet but deep and pervasive influence over a great deal of modern biological thought. Woodger stands in the mainstream of the great tradition of British empiricism; and his work marks the final repudiation of the metaphysical elements in Naturphilosophie.

Prof. D. R. Newth

Prof. Woodger's successor, Dr. D. R. Newth, is also a graduate of University College, London; and, like Woodger, he spent foux years on active service between graduating in zoology in 1942 and returning to postgraduate work in 1946. Prof. Newth is an embryologist and the son of an embryologist; but narrow sectarian classifications are no longer appropriate in biology, and he is best described as a biologist of unusually wide knowledge and sympathies whose main concern has been with the biological problems raised by embryogenesis. His first work was on the normal development of amphibian embryos. He then turned to the largely neglected problems raised by the evolutionary history of the neural crest, and undertook an experimental analysis of its behaviour and fate in lampreys. After an interlude in which he worked upon the reactions of hagfishes to light, he returned to morphogenetic problems. His was the first rigorous attempt to answer the question: Can an animal 'regenerate' a part which it never possessed ? In certain circumstances, he found, it can do so: by interfering with the primary embryogenesis of structures which are capable of regeneration in later life, they may develop abnormally; but these abnormalities can be partially made good if the abnormal part is amputated and so caused to grow anew. His analysis provides one possible approach to the problem of the persistence of post-embryonic life of the available genetic information in somatic cells. Newth's appointment will give particular pleasure not only to biologists in Great Britain but also to his many colleagues on the editorial board of the international Journal of Embryology and Experimental Morphology, in the foundation of which he was one of the prime movers.

\section{Forest Products Research Laboratory}

THE Council for Scientific and Industrial Research has reviewed the operation of the arrangements made early in 1958, under which it asked the Timber Development Association to assume responsibility for certain aspects of timber research previously discharged by the Forest Products Research Laboratory. The Steering Committee for the Laboratory had become convinced that the new arrangements did not allow sufficient latitude to the Laboratory in the discharge of its essential duties, and that the division of functions between the Laboratory and any other research organization must be more flexible. It was sure, therefore, of the need for a new approach to the problem of securing industrial support of work done for the immediate benefit of the timber trade (which was the aim of the earlier arrangements) and also to provide for the needs of the users-the home producer (including the Forestry Commission), the merchant and the manufacturer. At the same time it was regarded as essential to maintain an adequate and well-balanced research team at the Forest Products Research Laboratory. The Research Council has therefore re-stated its general policy for the Forest Products Research Laboratory in the following terms: "There is a continuing need in the national interest, both for research of a fundamental character on timber (but with ultimate practical applications) and for work of immediate benefit to the Forestry Commission and timber users. This work is best done at the Forest Products Research Laboratory with financial support from industry wherever possible. The Laboratory's programme should be co-ordinated with that of the Timber Development Association Research and Development Committee and/or of any Research Association which may be set up, but should primarily be devised to ensure that the interests of Government and the whole timber industry (producers and users, as well as merchants) are served to the best advantage". 